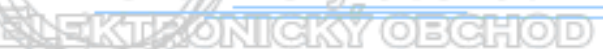

\title{
VYUŽITIE INTERNETU V MARKETINGOVOM VÝSKUME
}

\author{
Ing. Milan Kubina, PhD., Ing Viliam Lendel*
}

\section{Úvod}

V poslednom období má čoraz väčší význam pri získavaní dôležitých informácií internet. Ten ponúka nové možnosti zberu údajov v prieskume trhu. [2] Väčšinu informácií je síce možné získat' $\mathrm{z}$ iných zdrojov ako je internet, prístup $\mathrm{k}$ informáciám však môže byt' menej pohodlný a predovšetkým často vel'mi zdíhavý. Prostredníctvom internetu je každý krok účastníka na internete monitorovaný, čo umožňuje firmám získat' na ich serveroch dôležité údaje o potenciálnych zákazníkoch. Tieto údaje firma získava prakticky zadarmo.

V súčasnej dobe je základným predpokladom úspešného presadenia a udržania sa firiem na trhu schopnost' čo najlepšie pracovat' s informáciami. To sa týka ako schopnosti zberu, tak aj spracovania a využitia informácií. Marketingový výskum na internete prebieha najčastejšie v dvoch rovinách: [1]

- výskum prostredníctvom internetu,

- výskum internetu ako média.

\section{Informácie na Internete}

Firmy využívajú internet predovšetkým na vyhl'adávanie potrebných informácií. K tomuto účelu preferujú služby www serverov a elektronickú službu. Manažéri firiem tak môžu získat' informácie týkajúce sa ich práce. Sú to informácie umiestnené na stránkach iných spoločností, nezávislých inštitúcií, obsahujúce aktuálne správy, ceny akcií, výmenné kurzy jednotlivých mien a iné pre firmu zaujímavé informácie.

Informácie získané na internete je možné členit' do dvoch skupín, a to na: [1]

- odborné informácie (informácie o konkurencii, dodávatel’och, zákazníkoch, o stave ekonomike, možnostiach podnikania a vzdelávania, legislatívnych noriem, atd'.),

- všeobecné informácie (aktuálne spravodajstvo, spotrebitel'ské testy, cestovanie, zábava, atd'.).

\footnotetext{
* Ing. Milan Kubina, PhD., Ing. Viliam Lendel, Katedra menežérskych teórií, FRI, ŽU tel.: +421-41-5134323, fax: +421-41-5134451

e-mail: milan.kubina@fri.uniza.sk, Viliam.lendel@fri.uniza.sk
} 
Pre potreby marketingového výskumu je možné využit' viaceré informácie nachádzajúce sa na internete. Oblast' zist'ovaných informácií závisí na skúmanej problematike a na dostupnosti dát, ktorá je obmedzená predovšetkým financiami a taktiež aj prostredníctvom prístupových práv k určitým serverom. Vo všeobecnosti je možné pre potreby marketingového výskumu nájst' na internete predovšetkým nasledujúce informácie: [1]

- o firmách:

- vlastné prezentácie firiem na internete (identifikačné a popisné informácie, charakteristiky a zobrazenie produktov, finančné a ekonomické údaje),

- informácie od nezávislých zdrojov (katalógy, adresáre a registre firiem, ocenenie firiem),

- zo štátnych organizácií:

- informácie predovšetkým z ministerstiev, z obchodných a hospodárskych

- komôr (rozbory, analýzy, prehlásenia a prognózy uvedených organizácií, obchodný a živnostenský register, legislatívne normy, informácie o mestách),

- štatistické a demografické informácie:

- základné informácie je možné nájst' predovšetkým na serveri Slovenského štatistického úradu (údaje o SR, regionálne porovnanie, výsledky volieb, atd'.),

- od profesionálnych výskumných agentúr:

- výskumy o firmách, výskumy verejnej mienky, výskumy o internete,

- informácie z databázových centier,

- z iných médií:

- tlač, rozhlas, televízia,

- o zákazníkoch:

- analýza cookies,

- elektronické dopytovanie,

- štatistiky prevádzky www serverov, z predajných a objednávkových systémov,

- dotazníky na www serveroch vyplnené respondentmi (návštevníkmi).

\section{Marketingový výskum prostredníctvom internetu}

$\mathrm{Na}$ internete je možné aplikovat' všetky metódy marketingového výskumu (dotazníková metóda, pozorovanie, skupinové alebo híbkové rozhovory). Internet umožňuje získat' a pracovat' s takmer l'ubovol'nými údajmi. Tieto je možné analyzovat' na rôznych úrovniach a získavat' z viacerých zdrojov. Ďalším prínosom internetu je možnost' výmeny týchto informácií s inými l'ud’mi, prípadne koordinovat' prácu viacerých l'udí k požadovanému výsledku.

Pri využívaní sekundárnych údajov pre marketingové rozhodovanie je potrebné si uvedomit' tieto skutočnosti:

- informácie môžu byt' neaktuálne, skreslené, prípadne nejednoznačne publikované,

- napriek ich nevýhodám sú dôležité $\mathrm{k}$ základnej orientácii riešenej problematiky,

- je potrebné ich overit' z viacerých nezávislých zdrojov.

V súčasnosti pre riešenie informačných systémov vo vnútri organizácie sa začínajú využívat' internetové technológie, ktoré sú nazývané intranetom. 
Intranet pracuje na rovnakom princípe a s rovnakými nástrojmi ako internet, ale je určený pre uzavretý okruh osôb, pre pracovníkov jednej firmy. Základným prínosom intranetu vo firme je zabezpečenie čo najrýchlejšieho prístupu k požadovaným informáciám, zaistenie ich aktuálnosti, zrozumitel'nosti a ich vysokej vypovedacej schopnosti.

K l’ahkému vyhl'adávaniu informácií na internete slúžia globálne vyhl'adávacie služby, tzn. vyhl'adávače. [1]

\section{Výskum internetu ako média}

Internet je v tomto prípade využívaný ako médium, prostredníctvom ktorého je možné získat' potrebné údaje pre realizáciu marketingového výskumu a môže byt' použitý pri niektorých technikách zberu údajov.

Firmy majú predovšetkým záujem o čo najpresnejšie informácie o tom, kol'ko l'udí videlo ich reklamu, či bola resp. nebola účinná. Preto medzi najsledovanejšie informácie na internete patria: [1]

- počet užívatel'ov internetu,

- počet návštevníkov serveru,

- počet zobrazení reklamného bannera,

- účinnost' reklamného bannera.

Využívanie internetu na účely marketingového výskumu má svoje výhody i nevýhody. Ich prehl'ad v jednotlivých metódach zberu údajov je znázornený v tabul'ke 1.

Tabul'ka 1 Výhody a nevýhody pri uplatnení internetu v metódach zberu údajov [1]

\begin{tabular}{|l|l|l|l|}
\hline & metódy zberu údajov & \multicolumn{1}{|c|}{ výhody } & nevýhody \\
\hline primárny zdroj & - elektronické & - rýchlost' zberu & - nemožnost' oslovit' \\
& dopytovanie & - nízka cena & všeobecnú \\
& - elektronické & - presne určená & populáciu \\
& pozorovanie & a známa ciel’ová & - obmedzená \\
& - experiment & skupina & možnost' využitia \\
& v elektronickom & & kvalitatívneho \\
& prostredí & & výskumu \\
\hline sekundárny zdroj & - externé zdroje & - rýchlost' zberu & - kvalita dát \\
& - interné zdroje & - nízka cena & - skreslenost' údajov \\
\hline
\end{tabular}




\section{Záver}

V Internet má, ako prostriedok na prieskum, obrovský potenciál v odhal'ovaní a zist'ovaní informácií, ktoré by sa klasickou prieskumnou cestou len t’ažko zist'ovali. Prináša vel'ké úspory, časové i finančné. [2]

V súvislosti s rýchlym rozvojom informačných technológií a využívaním ich možností predpokladá sa čoraz väčšie využívanie internetu vprocese marketingového výskumu. Význam internetu ako zdroja informácií je vel'ký a bude nad'alej rást'. Stále sa vyvíjajú nové technológie a softwarové prostriedky pre l'ahšie a rýchlejšie vyhl'adávanie a získavanie požadovaných informácií. Napriek tomu bude náročné v informačnej explózii na internete nájst' kvalitné údaje. $Z$ tohto dôvodu je potrebné pri marketingových výskumoch kombinovat' metódy získavania údajov prostredníctvom internetu s klasickými metódami. [1]

\section{Literatúra}

[1] KOZEL, R.: MODERNÍ MARKETINGOVÝ VÝZKUM. PRAHA: GRADA PUBLISHING. 2006. ISBN 80-247-0966-X

[2] RICHTEROVÁ, K.: MARKETINGOVÝ VÝSKUM. BRATISLAVA: EKONÓM. 2005. ISBN 80-225-2064-0

[3] MATEIDES, A., ĎAĎO, J.: SLUŽBY. BRATISLAVA: EPOS. 2002. ISBN 80-8057452-9

[4] PŘIBOVÁ, M.: MARKETINGOVÝ VÝZKUM V PRAXI. PRAHA: GRADA PUBLISHING. 1996. ISBN 80-7169-299-9 